\title{
Forgotten Romantic and Enlightenment Connections: A personal approach to Mollenhauer's seminal works
}

\author{
Stefan T. Hopmann, University of Vienna, Austria \\ stefan.hopmann@univie.ac.at
}

\section{Erziehung und Emanzipation - Education and Emancipation}

There are many ways to situate Enlightenment and Romantic traditions in Continental educational history, not the least in German-speaking countries. Moreover, between the histories of Enlightenment and Romanticism, we have to add a third strand, which is normally considered as the "Classical" period of educational theorizing, connected to names like Humboldt, Herbart, Schleiermacher and sometimes Hegel (cf. for example, Klafki 1986). They are credited for having shaped the specific German tradition of "Bildungstheorie", a concept hardly possible to translate into English. Klaus Mollenhauer's works have been linked to all of them, depending on where one sees the key ingredients of his approach. I will not try to present a historical account of this background, but rather move on to a very personal approach to this issue's meaning for me in my educational biography.

The very first book by Mollenhauer that I read was a small volume of collected essays, which was published in 1968, and titled Education and Emancipation. I was 16 or 17 then, a member of the State Student Board and later, its President. I had already had my fair share of Marxism and critical theory before by chance bumping into Mollenhauer's book. I bought it because of the title. I was desperately looking for theories that could tell us in the student movement how to shape education and schooling in a way that fostered the emancipation of the disadvantaged in society. The big theories were good at explaining why we were where we were, but they were unable to point to ways of how to bring about change.

It is obvious in my copy of the book I stopped reading it closely after the introduction and the first chapter. Somehow, I must have been disappointed. Of course, the book carried the familiar references to critical theory from Adorno to Habermas, but it was definitely not a part of that movement. "Reason", the concept that Adorno and Horkheimer (1968) had so thoroughly deconstructed in their book on the dialectics of enlightenment, still seemed to play a prominent role in Mollenhauer's thinking. Moreover, he used concepts like "functionality", rather more typical for post-Parsonian thinking than for critical theory. Finally, this was mixed with elements of the "geisteswissenschaftliche Pädagogik", which was considered stone dead at that time. Looking back, I would say that I did not trust any rational re-conceptualizing of enlightenment, which seemed to be at the core of the book, as an answer to the social struggles of the time. I was not able to understand and systematize all these relations then. But I simply felt that there was no clear answer in the book on how to emancipate the children of the working class - and no less was my final goal as student representative back then.

\section{Theorien zum Erziehungsprozess - Theories on the Education Process}

The second book of Mollenhauer, which I came to read, was his volume entitled Theories on the Education Process, first published in 1972, my copy being from 1976. I was an undergraduate student of Education and Sociology back then, still searching for theories that could explain my own experience to me. This time I was interested in why the working class or, more 
exactly, their children quite obviously were not very interested in being emancipated by folks like me. Besides being a student, I was doing all kinds of courses for the German Union Association and local Junior High schools, all focused on "awakening" the social consciousness of the students with which I had to deal. To be honest, while they seemed to like my way of teaching, they didn't care about my political intentions. They seemingly tolerated my political musings as long as we had fun or did things that had practical value (such as job interview training). My undergraduate thesis (1976) therefore focused on exactly the question of what kept people from developing class-consciousness and what education might be able to do about it.

This time I did it the hard way: I worked through the whole book, page-by-page, even re-reading chapters when I felt I might have missed something. The book sketched out a system, which was not so unusual at the time. It used different theories to explain different levels of the educational process: Apel's communication philosophy for the interpersonal contact; Mead's interactionism for the level of interaction in organizations and institutions; critical theory and a bit of Marx for the societal level. Psychoanalysis, phenomenology, or humanistic psychology were also added, resulting in a more or less critical or Marxist theory of society.

Yet, Mollenhauer (1976) disappointed me again. He still seemed to be stuck in the Enlightenment project, or as he writes on page 81: "Education cannot be more than organized enlightenment." In this he sees both the power and the limitation of education as intentional intervention or profession. "Organized enlightenment" -what might that be? Surely this is not the kind of organized education provided by the diverse Communist movements on both sides of the Wall. Their project seemed to be more Hegelian than Marxian to me, in that they tried to force the will of their spirit on the people, regardless of the people's aspirations. My key issue with this was that they were unable to explain why, when and how the people themselves would be able to develop class-consciousness in the way Marx had predicted in his early writings (e.g., the Paris Manuscripts or the German Ideology; both among my favourites then). Mollenhauer seemed to assume that some sort of "communication" could pave the way to critical Bildung. But he was not very specific on details as to what kind of communication this would be, and my own experience had been that communication alone was not to be strong enough to trigger enlightenment.

Later, I came to try another "way out", which was somehow in the air then among us young critical scholars: theories on everyday life. They moved beyond mere communication, to which Habermas and Mollenhauer seemed to limit their project, towards an attempt to understand what shaped the lived experience of those living more or less in an oppressed way in Capitalist societies (as well as in their, by name only, Socialist counterparts). Thus I came to write my Masters thesis on the issue of "Alltag, Bildung und Entfremdung" (1980). "Everyday life, education and alienation" is a very poor translation of what this was about, as each of these concepts carries a very long history of connotations and sub-meanings, going back to - yes indeed - the early Romantic movement, for example, Novalis and Jean Paul, in whose writings the concept of "everyday life" showed up for the very first time. Likewise there were connections to the Classical period, and authors like Humboldt, who would talk about education through interpersonal communication and experience as key to everything, and the risk of alienation. I followed the argument through including Marxist perspectives like Lukacs, Bloch and Lefebvre as well as phenomenology. Alfred Schütz was the most important source of inspiration. My answer to the problem was that it was the small "ruptures" experienced contradictions between official knowledge and everyday experience, which should be the starting point of any critical education.

\section{Vergessene Zusammenhänge - Forgotten Connections}

My hope of giving my ideas a practical application while working for trade unions and labour organizations was not very successful. Left-wingers did not feel I was Marxist enough, right- 
wingers felt uncomfortable with my academic approach to education, and both accused me of being impractical in my doings. After just two years in the field, I had to leave. At the time, as a single father of twins, the only way I was able to find a way out of my predicament was to accept a research position at the Institute for Science Education (IPN) in Kiel, where I was supposed to do a study on how school curricula (guidelines) are made, changed, and applied. This was not exactly what I had been dreaming of!

However, was not school the single most important institution in which the social consciousness of people can be shaped, if not submerged by the official narratives? Should I not use this opportunity to figure out how "they" managed using schools for their purposes? How "they" (whoever "they" were) were able to make people believe, while critical forces were unable to have a similar influence. My idea was that I would have to understand what makes those who develop and impose curriculum do what they do. How to get there?

In Germany, curriculum guidelines are developed by State administrations, a tradition that goes back to Humboldt and Schleiermacher. I set out to reconstruct the history of curriculum, as well as making an empirical study on those currently involved in that business (Hopmann, 1988). Had I expected some capitalist forces doing their hidden business in the back rooms of curriculum making, I was unable to find them. Actually, as it turned out, I found that it had always been teachers, more exactly, administrators who had been former teachers, who were responsible for the development and implementation of curriculum guidelines. Once in a while, there were attempts to involve other social-interest groups in curriculum making. But they had never had a significant impact; in fact, if involved at all, they behaved rather like would-be teachers, using similar arguments and ideas. Moreover, the big social issues never played a significant visible role in curriculum making. Rather, what was being done was a kind of practical reasoning based on former teaching experience and current developments in schools. In short, "curriculum making" turned out to be an "administrative behaviour" (hence the title of my $\mathrm{PhD}$ thesis).

When Mollenhauer's book appeared in the mid-1980's, I was right in the middle of my study on curriculum making. Perhaps this is reason why Mollenhauer disappointed me again. There, I was trying to understand the soft power of administration, while he suddenly dropped the Enlightenment project in favour of a somewhat Romantic relapse into big education narratives. What did he say that we had forgotten? The cultural embedding of all education? What culture are we talking about? The anthropological bases of education as the meeting point between an older generation and a younger one, as Schleiermacher had once put it? This is the same Schleiermacher who invented the basic features of what curriculum guidelines could and should be a framework so powerful that it is easy to identify its impact, for example, by looking at modern common core standards. From my perspective, Schleiermacher had moved beyond the realms of grand theorizing by addressing the question of how to put this into large-scale work. Where Mollenhauer (using Schleiermacher) talks about presentation and representation, and the necessary selection included in this act, I was dealing with the question of how such selections actually happened in schooling, and there was not much Romanticism to be found there.

\section{The Forgotten Link}

To be honest, I got Mollenhauer wrong every time! His earlier works were neither simple reconceptualizations of the Enlightenment project, nor was his later work a Romantic relapse. His trajectory was always closely connected to the issues: Is education possible, and if so, how? And how can education empower or emancipate those being educated? This was not so different from my own problems. But Mollenhauer was, of course, always a step ahead of what I was able to appreciate. 
The missing link, the point I did not grasp, was his continuous insistence on something that I had considered as a weak left-over of the "geisteswissenschaftliche Pädagogik": the pedagogical relation, as Mollenhauer's teacher, Herman Nohl (1957), had called it (der pädagogische Bezug). This pedagogical relation had one important pre-condition, which had been shown by the Classics, i.e. Humboldt, Schleiermacher, and, not the least, Herbart, namely, the concept of "educability" (Bildsamkeit). The pedagogical relation can only happen if the one who is to be educated can be educated. But the concept of educability carries more than that, namely the idea that all education is basically self-education (Humboldt). The one educated must educate him- or herself. The only thing that educators can do is to provide guidance for this self-education. The key point in this is kind of Rousseauian: autonomy or emancipation is not something created by education. "Everything is good as it leaves the hands of the Author of things; everything degenerates in the hands of man" is, after all, the opening sentence of Rousseau's Emile. Education, rather, has to ensure that this autonomy is not destroyed or kept at bay by other forces, thus enabling the child to develop his or her own identity and sociability.

However, Mollenhauer (like Humboldt \& Co.) does not have a Romantic view on this inner nature of the child. When we are born, we are weak, without knowledge and understanding. There is no inner nature guiding us through what is going to happen to us. We are put into a given world with all its constraints and conditions. That is what Rousseau tries to avoid by moving the child out of the reach of civilization, but only as a thought experiment, not as an intentional practice. This world, as it is, is present already through the very persons caring for us in the beginning, our parents, or guardians. Here, we have to recall the famous point of Marx in his third Feuerbach thesis: Those who want to educate tend to forget that the educators have been educated themselves! Or in Mollenhauer's view: Whatever we do, we present a way of living simply by being the way we are. Later on, when other educational forces such as schools move into the picture, we have to choose carefully the kind of world we want them to re-present.

In any case, this has to happen in a way that does not overpower the child, but rather nurtures his or her abilities for self-education. Again, this is not just a careful Romantic relation, at least not in the world we are living in. We confront the child with the world as it is, with the world's and our own shortcomings, and our own socio-cultural embedding. For professionals, this requires a dialectical approach to education, like the one Schleiermacher developed in his 1813-1826 lectures, which sees nature and culture, power and enlightenment as interacting, inter-woven elements of the world we are in. In this sense, Forgotten Connections recapitulates earlier versions of the pedagogical relation as well as its current whereabouts, asking for what seems to be unavoidable, namely anthropological ingredients, and that which is bound by time and space.

This roots the education process in more than just interpersonal communication, as would seem to be the case in Mollenhauer's earlier works. This communication is necessarily embedded in the power structures as well as the contradictions of the time and place in which we grow up. This is more than "organized enlightenment"; simply hoping for the power of reason in a world in which reason has a dialectical undercurrent that can backfire. This is more than believing in the innocent nature of the child, like the Romantics did, let alone the biological and racial travesties shaping later emanations of Romantic pedagogy. It is situating the act of education in between, by insisting on the power of enlightenment without forgetting the forces of nature and culture.

But there is a price to pay for this advanced position in the pedagogical relation. If the idea of self-education is meant seriously, there is no way of getting to a position from which we can give final answers to the question of what education is and should be. Any attempt to finalize educational theory (or the curriculum) would ignore both the given autonomy of those being educated and the socio-historical embedding of any answer to the question of what we are aiming for when educating and teaching. Therefore, Forgotten Connections repeats time again the preliminary and limited nature of its efforts, not because the final version has not yet 
been made, but because there are no final answers. Each and every pedagogical relation is a new beginning, asking for its own answers in time and space.

In this sense, it is my children, and, nowadays, my grandchildren, who taught me how to appreciate Mollenhauer's position. My early intention of figuring out how to educate the masses was simply arrogant, as it made my insights the parameter of other people's living and education. I was not even able to educate my own children according to my ideas! What I did learn in education, teaching, and research on curriculum-making was how much we all are embedded in our time and space, how much that shapes our doings irrespective of the grand narratives that are told about why society is the way it is or school does what it does.

Yet, these limits of education are not a pity, but a gift. Try to imagine for a second that we could indeed shape our children at will. Would we not be ready to overpower whatever they might have in mind because we, as educators, believe we know best? Our children would become poor copies of our grand ideas, left or right, enlightened or romantic, empirically or reconceptually grounded (or whatever else sets us on fire). Humans may be in need of education, but happily they are always just as capable of being more than and growing beyond what we wanted them to be. And it is this connection to what the pedagogical relation is about that we should not forget: "Restraining" (Hopmann 2007) our education and teaching in the hope that those who follow us will come up with better solutions than the ones we had thought of when we planted our children into our world without asking them first if they wanted to be a part of it.

\section{References}

Horkheimer, M. / Adorno, T.W. (1968). Dialektik der Aufklärung. Frankfurt: Fischer.

Hopmann, S.T. (1976). Bildung und Klassenbewusstsein. unpubl. Undergraduate Thesis. Giessen: Justus-Liebig-Universität

Hopmann, S.T. (1980). Alltag, Bildung und Entfremdung. Unpubl. MA-Thesis. Giessen: Justus-Liebig-Universität

Hopmann, S.T (1988). Lehrplanarbeit als Verwaltungshandeln. Kiel: IPN.

Hopmann, S.T. (2007). Restrained teaching: The common core of didaktik. European Educational Research Journal, vol. 2, 109 - 124.

Klafki, W. (1986). Die Bedeutung der klassischen Bildungstheorien für ein zeitgemässes Konzept allgemeiner Bildung. In: Zeitschrift für Pädagogik; p. 455 - 476.

Mollenhauer, K. (1968). Erziehung und Emanzipation. München: Juventa. .

Mollenhauer, K. (1976). Theorien zum Erziehungsprozess. München: Juventa.

Mollenhauer, K. (1983). Vergessene Zusammenhänge. Über Kultur und Erziehung. München: Juventa.

Nohl, H. (1957). Die pädagogische Bewegung in Deutschland und ihre Theorie. Frankfurt: Fischer.

Schleiermacher, F. D. E. (1826/1956). Vorlesungen zur Erziehung aus dem Jahre 1826. In Schleiermacher, F.D.E.: Schriften. Vol. 1. Düsseldorf: Schwan. 